\title{
Bimodal Behavior of Ascorbic Acid in Musca domestica
}

\section{Larvae}

\author{
Prajakta A. Dhage ${ }^{1}$, Archana A. Sharbidre 2,*(D) \\ 1 Department of Zoology, K.R.T. Arts, B.H. Commerce and A.M. Science College (KTHM College), Nashik-422002; \\ dhageprajakta@gmail.com (P.A.D.); \\ 2 Department of Zoology, Savitribai Phule Pune University, Pune 411007, MS, India \\ * Correspondence: aasharbidre@unipune.ac.in (A.A.S.);
}

Scopus Author ID 43561688500

Received: 23.07.2021; Revised: 5.09.2021; Accepted: 9.09.2021; Published: 17.10.2021

\begin{abstract}
Ascorbic acid (Vitamin C) is an excellent water-soluble dietary antioxidant, well known to protect the biomolecules from oxidative stress-linked damages. It is reported to show a contrary behavior by inflicting pro-oxidant effects under varied, altered circumstances. The present work is an attempt to study the antioxidant and pro-oxidant behavior of ascorbic acid in Musca domestica larvae. Its pro-oxidant properties were tested by exposing the larvae to various concentrations of ascorbic acid. For confirming its oxidant scavenging properties, its effects on the antioxidant enzyme profiles were studied in both the normal and stress-induced $M$. domestica larvae. Oxidative stress was induced by adding D-Galactose (D-Gal) to the normal food supplement of the larvae. Outcomes of the study demonstrate that ascorbic acid acts as an efficient antioxidant when added in lower concentrations, but at high concentrations, it induces oxidative stress in the larvae, thus acting as a pro-oxidant. At the concentration of $10 \mathrm{mM}$, ascorbic acid significantly reduced the oxidative stress induced by D-Gal $(\mathrm{p}<0.05)$ and maintained the percent pupal survival and percent eclosion. In conclusion, we suggest that ascorbic acid may function as an antioxidant and pro-oxidant in a concentration-dependent manner under normal physiological conditions.
\end{abstract}

Keywords: ascorbic acid; pro-oxidant; antioxidant; D-galactose; Musca domestica larvae; oxidative stress.

(c) 2021 by the authors. This article is an open-access article distributed under the terms and conditions of the Creative Commons Attribution (CC BY) license (https://creativecommons.org/licenses/by/4.0/).

\section{Introduction}

Ascorbic acid, a water-soluble vitamin, is well known for its antioxidant potential. It generally exists in two forms: L-ascorbic acid and L-dehydroascorbic acid under physiological conditions [1]. Amongst this, L-ascorbic acid is the major dietary form with potent free radical scavenging activity. Free radicals are the major byproducts of oxygen metabolism and are continuously released into the cell under normal physiological conditions [2- 4].

Excessive free radicals are known to exhibit deleterious effects on the biomolecules leading to several cellular malfunctions [3,5]. An integrated network of the enzymatic antioxidant systems inside the cells is known to balance these excessively produced free radicals [6-8]. Along with this internal antioxidant defense system, dietary antioxidants and vitamins are also known to play an important role in preventing the uncontrolled generation of these free radicals or inhibiting their reaction at biological sites [9-12]. In order to efficiently scavenge the free radicals, antioxidants require to donate an electron or an active hydrogen atom to these free radicals. 
Ascorbic acid provides this active hydrogen atom, which in turn pairs with the unpaired electron or free radical. It results in the formation of an un-reactive ascorbyl radical, which does not affect the integrity of biomolecules [1, 13]. Conversely, few in vitro studies on ascorbic acid have also elucidated its pro-oxidant effects under specific conditions such as the presence of transition metals, excessive oxygen, and various pathological conditions [14-18]. The pro-oxidant property of ascorbic acid is also used as a potent apoptotic agent against cancerous cells [19-21].

The objective of the present study was to determine the antioxidant and pro-oxidant behavior of Ascorbic acid in vivo in the housefly, M. domestica larvae. In order to study the antioxidant properties of Ascorbic acid, the larvae were introduced to the D- Galactose (hereafter referred to as D-Gal) in order to induce stress in them. D-Gal, a reducing sugar, is a known physiological nutrient. However, over ingestion may cause osmotic stress due to the production of Reactive Oxygen Species, which results in abnormal metabolism [22, 23]. Numerous workers have used D-Gal to induce oxidative stress in a variety of animal models in order to study different parameters of stress and antioxidants [24-36].

To date, in order to study the antioxidant effects, only the adult diet was manipulated. However, the current study aims to examine the effect of larval supplementation on adult eclosion and pupation. The transitional behavior of Ascorbic acid in M. domestica larvae was determined under normal as well as oxidative stress conditions by measuring lipid peroxidation (LPO), protein carbonylation (PCC), and activities of antioxidant enzymes such as superoxide dismutase (SOD), catalase (CAT), glutathione S-transferase (GST) and ascorbate peroxidase (APOX)

\section{Materials and Methods}

\subsection{Chemicals.}

Ascorbic acid, D-Galactose, methylparaben, and Sulforhodamine B were acquired from Sigma Chemical Co., St. Louis, USA. All analytical grade chemicals were utilized for the experimental work.

\subsection{Fly stock rearing.}

Housefly nucleus culture was obtained from the National Chemical Laboratory, Pune, India, and was acclimatized in the laboratory at $26 \pm 1^{\circ} \mathrm{C}$ with $70 \pm 1 \%$ Relative Humidity (RH). The eggs were developed in a control diet up to the pupal stage. The pupae were separated and kept in another container for adult emergence. The second generation of $M$. domestica larvae was used for experimentation.

\subsection{Diet.}

The experimental diet was formulated as per earlier studies carried out in our laboratory (unpublished data). The control diet comprised $9 \mathrm{gm}$ soya food (4 gm soya powder $+2 \mathrm{gm}$ rice bran $+1.5 \mathrm{gm}$ milk powder) mixed well in $15 \mathrm{ml}$ of distilled water. Streptomycin and methylparaben were added to the diets for circumventing the microbial infection. 20 larvae were used per experimental set. 


\subsection{D-Gal concentration and treatment to larvae.}

Based on the previously reported data from our laboratory, a concentration of $6 \mathrm{mg} / \mathrm{ml}$ was selected for the experimentation [37].

\subsection{Selection of Ascorbic acid concentration and treatment to larvae.}

Diverse concentrations of ascorbic acid such as 20,40,60, 80, and $100 \mathrm{mM}$ were prepared. The $M$. domestica larvae were reared on diets containing these concentrations up to the third instar, and larval survival was observed. It was found that all the concentrations showed high mortality, except for the concentration of $20 \mathrm{mM}$. Although $20 \mathrm{mM}$ dose showed less mortality, the survival percentage of larva significantly differed from that of control. Further reduction in the ascorbic acid concentration was made. The larvae were treated with 10,15 , and $20 \mathrm{mM}$ concentrations of ascorbic acid. Larvae reaching the third instar stage were crushed in phosphate buffer and used for further biochemical assays such as LPO, SOD, CAT, and PCC. Based on the findings of these assays, $10 \mathrm{mM}$ concentration was selected for further D-Gal-induced oxidative stress studies.

\subsection{Antioxidant effect of Ascorbic acid against D-Gal-induced oxidative stress.}

For this study, larvae ( $n=20 /$ replicate; 5 replicates per group) were exposed to four diet groups as, 1) control, 2) $10 \mathrm{mM}$ ascorbic acid (hereafter referred to as $10 \mathrm{mM} \mathrm{Asc}$ )., 3) 6 $\mathrm{mg} / \mathrm{ml} \mathrm{D}$ - Galactose, (hereafter referred to as D-Gal) and 4) $10 \mathrm{mM}$ ascorbic acid + 6mg/ml Dgal (hereafter referred to as D-Gal $+10 \mathrm{mM}$ Asc). Third instar larvae from control and various treatment groups were used for biochemical analyses.

\subsection{Gustatory assay.}

The amount of food intake by house fly larva was assessed by adding Sulforhodamine $\mathrm{B}$, a visible dye, into the diets, and after that gut redness was measured [38]. Recently hatched first instar larvae were transferred on the four food sets up to the second instar stage. At the late second instar stage, these larvae from each group were left unfed for 24 hours on tissue paper soaked in distilled water. At the end of the starvation period, larvae were again relocated on their corresponding experimental food set blended with $2 \%$ sulforhodamine B. Larvae were fed for 3 hours on the dye-blended food. Later these larvae were placed on ice for immobilization and then dissected. The entire larval gut was dissected and homogenized in 0.1 M phosphate buffer, $\mathrm{pH} 7.2$. The optical density of the supernatant was measured at $540 \mathrm{~nm}$ using a microplate reader.

\subsection{Biochemical assays.}

\subsubsection{Antioxidant enzymes.}

Post-treatment, 10 third instar larvae from each of the four groups were collected. Immobilization of the whole larvae was done on ice. These whole larvae were then homogenized separately in the respective assay buffers and centrifuged at $3000 \mathrm{rpm}$ for $15 \mathrm{~min}$ at $4^{\circ} \mathrm{C}$. Further centrifugation of the supernatant was done at $12,000 \mathrm{~g}$ for $10 \mathrm{~min}$ at $4^{\circ} \mathrm{C}$. The supernatant obtained from this centrifugation was stored at $-80^{\circ} \mathrm{C}$ and later used within a week for further analysis. 
2.8.1.1. Superoxide dismutase (SOD).

For this assay, in $50 \mathrm{mM}$ sodium phosphate buffer ( $\mathrm{pH} 7.0), 10$ whole larvae of the third instar stage were homogenized and later centrifuged $\left(12,000 \mathrm{~g}\right.$, for $10 \mathrm{~min}$, at $\left.4^{\circ} \mathrm{C}\right)$. SOD activity was measured by formazan inhibition in the presence of the enzyme [39]. Calculation of enzyme activity was done as units/mg of protein.

\subsubsection{Glutathione-S-transferase (GST)}

Similarly, the GST activity of supernatants was measured using 1-chloro-2, 4dinitrobenzene (CDNB) as substrate as per the method developed by Habig et al. (1974) [40]. The enzyme activity was calculated as nmol CDNB conjugate formed min/mg protein. A molar extinction coefficient of $9.6 \mathrm{mM}-1 \mathrm{~cm}-1$ was used.

\subsubsection{Catalase (CAT).}

Third instar whole larvae (10) were homogenized in $66 \mathrm{mM}$ phosphate buffer ( $\mathrm{pH} 7.0)$, centrifuged at $8000 \mathrm{~g}$ for $5 \mathrm{~min}$ at $4{ }^{\circ} \mathrm{C}$. Supernatants were used for measuring enzyme activity. Abei's (1984) method was used to calculate catalase activity which was expressed as mmol $\mathrm{H}_{2} \mathrm{O}_{2}$ reduced per min (= $\left.1 \mathrm{EU}\right)$ per $\mathrm{mg}$ of protein using extinction coefficient $39.4 \mathrm{mM}^{-1} \mathrm{~cm}^{-1}$ [9].

\subsubsection{Ascorbate peroxidase (APOX).}

$0.3 \% \mathrm{H}_{2} \mathrm{O}_{2}$ was added in all the supernatants ( $\mathrm{pH} 7.0$ ) containing $0.5 \mathrm{mM}$ ascorbic acid, and then a decrease in absorbance was measured for $10 \mathrm{~min}$ at $290 \mathrm{~nm}$. Boiled samples were concurrently analyzed. Enzyme activity was expressed as mmol ascorbate oxidized per min (= $1 \mathrm{EU})$ per mg of protein using $2.8 \mathrm{mM}^{-1} \mathrm{~cm}^{-1}$ as molar extinction coefficient.

\subsubsection{Lipid peroxidation (LPO).}

The peroxidation of lipids (LPO) was evaluated using the thiobarbituric acid (TBA) reactive substances (TBARS) assay method [41]. Results are expressed as nmoles of malondialdehyde (MDA) per gm wet tissue. LPO was calculated as nanomoles of TBARSformed per gm of tissue using a molar extinction coefficient of $1.56 \times 10^{-5} \mathrm{M}^{-1} \mathrm{~cm}^{-1}$.

\subsubsection{Acid phosphatase (ACP).}

The ACP activity was measured using the method described by Linhardt and Walter (1963) with some modifications [42]. The assay mixture contained $20 \mu \mathrm{l}$ of supernatant and $0.3 \mathrm{ml}$ of citrate buffer ( $\mathrm{pH} 4.0$ ) using $5.5 \mathrm{mM}$ p-nitrophenyl phosphates as substrate. The assay tubes were incubated at $37^{\circ} \mathrm{C}$ for $5 \mathrm{~min}$. For stopping the reaction, $0.7 \mathrm{ml}$ of $1.25 \mathrm{M} \mathrm{NaOH}$ was added. Later the absorbance was taken at $405 \mathrm{~nm}$. Calculation of ACP activity was done in terms of units formed per mg of tissue using the molar extinction coefficient $18.8 \mu \mathrm{M}^{-1} \mathrm{~cm}^{-1}$ of -nitrophenol.

\subsubsection{Protein carbonylation assay (PCC).}

Reznick and Packer's (1994) method was used to measure protein carbonyl content [43]. The concentration of carbonyls was quantified at $370 \mathrm{~nm}$ and calculated in terms of $\mathrm{nmol} / \mathrm{mg}$ protein, using molar extinction coefficient $22 \mathrm{mM}^{-1} \mathrm{~cm}^{-1}$. Bovine serum albumin 
(BSA) standard curve was used to quantify protein concentration in the guanidine solutions by measuring absorption at $280 \mathrm{~nm}$.

\subsubsection{Determination of protein concentration.}

The concentrations of protein in all test samples were calculated by using the Bradford reagent [44]. Bovine serum albumin (BSA) was used as the standard.

\subsection{Effect of ascorbic acid and D-Gal on pupal viability and percent eclosion studies.}

In order to study the effect of the larval supplement of ascorbic acid and D-Gal on the pupation and eclosion of $M$. domestica, larvae were grown on each of the four treatment groups in 5 replicates $(n=20)$. The larvae were allowed to pupate, and a number of pupae formed were recorded. The number of flies ecloded from the pupa was counted, and the percentage of eclosion was calculated.

\subsection{Statistical analysis.}

All experiments were repeated in triplicate. Results analysis was based on the significance of differences between control and exposed larvae by one-way analysis of variance (ANOVA), followed by Tukey's test (means comparison) performed by applying a statistical software, SPSS -2011. Significance was set at $p<0.05$. All data values were presented as mean \pm standard error (SE). Means sharing the same letter represent no statistical significance, $\mathrm{p}<$ 0.05 .

\section{Results and Discussion}

\subsection{Selection of ascorbic acid concentration.}

The present study on $M$. domestica larvae documents the bimodal behavior of ascorbic acid in vivo in a concentration-dependent manner. Pro-oxidant behavior was attributed to its lethal effects on the larvae at higher concentrations of $60 \mathrm{mM}, 80 \mathrm{mM}$, and $100 \mathrm{mM}$, whereas antioxidant behavior to its oxidative stress-reducing effect at $10 \mathrm{mM}$ concentration in the DGal challenged larvae. There was a significant decline in larval survival with increasing doses of ascorbic acid (Figure. 1). Maximum survival was found at $20 \mathrm{mM}$ ascorbic acid, whereas maximum larval mortality was observed at the concentrations of $60 \mathrm{mM}$ and $80 \mathrm{mM}$ (Figure. 1). $100 \mathrm{mM}$ Ascorbic acid concentration showed $100 \%$ mortality. Further fine standardization of ascorbic acid at lower concentrations was performed using antioxidant assays. There was observed a significant increase in SOD and PCC activity at $15 \mathrm{mM}$ and $20 \mathrm{mM}$ concentrations of Ascorbic acid ( $p<0.05$ and $p<0.01$ respectively) as shown in Figure. 2. But the activity of both enzymes did not significantly differ amongst the control and $10 \mathrm{mM}$ concentration groups. The LPO values of $15 \mathrm{mM}$ and $20 \mathrm{mM}$ groups were significantly higher than the control and $10 \mathrm{mM}$ ascorbic acid groups ( $\mathrm{p}<0.05$ and $\mathrm{p}<0.01$, respectively). However, the LPO values of the control and $10 \mathrm{mM}$ Asc treated group showed no significant difference.

This dual behavior of ascorbic acid was previously reported in vitro by many of the workers $[15,18,45]$. Its pro-oxidant behavior has been documented by various studies. Osiecki et al. 2010 stated that the particular activity of Ascorbic acid is the function of its amount of dose, time, and cellular location [46]. According to Scheffler et al. (2019) it brings about glycation of the cellular proteins and interferes with the viability and outgrowth of neuritis [47]. 
Ascorbic acid at higher doses is reported to damage DNA by excessive generation of $\mathrm{H}_{2} \mathrm{O}_{2}$ [48]. Moreover, it also exhibits its pro-oxidant nature in the presence of certain metals $[49,50]$. A higher concentration of ascorbic acid is known to augment mortality owing to its cytotoxic and pro-oxidant properties [51]. Dietary supplementation studies have illustrated that ascorbic significantly improves mice's average life span but shortens in guinea pigs [52- 54]. The nature of ascorbic acid as a pro-oxidant is a debatable issue and has been very carefully worked out by Carr and Frei (1999) [55]. Studies performed on various cell lines demonstrate that a higher concentration of Ascorbic acid is an efficient therapeutic against cancer [18, 20, 56-59]. The above studies are in accordance with our results, where at the concentration of $80 \mathrm{mM}$ and $100 \mathrm{mM}$ maximum larval mortality was observed. We suggest that increase in mortality with increasing concentration of ascorbic acid may be mainly due to the extracellular auto-oxidation and $\mathrm{H}_{2} \mathrm{O}_{2}$ production. Under aerobic conditions, Ascorbic acid can react with molecular oxygen to produce superoxide radicals. This results in dismutation to $\mathrm{H}_{2} \mathrm{O}_{2}$, which can pass enter the cells and react with reduced metal ions to generate destructive $\mathrm{OH}$ radicals [60]. Ascorbic acid supplementation only delays oxidation before its initiation but will further augment oxidation when added to minimally oxidized Low-density lipoproteins [61].

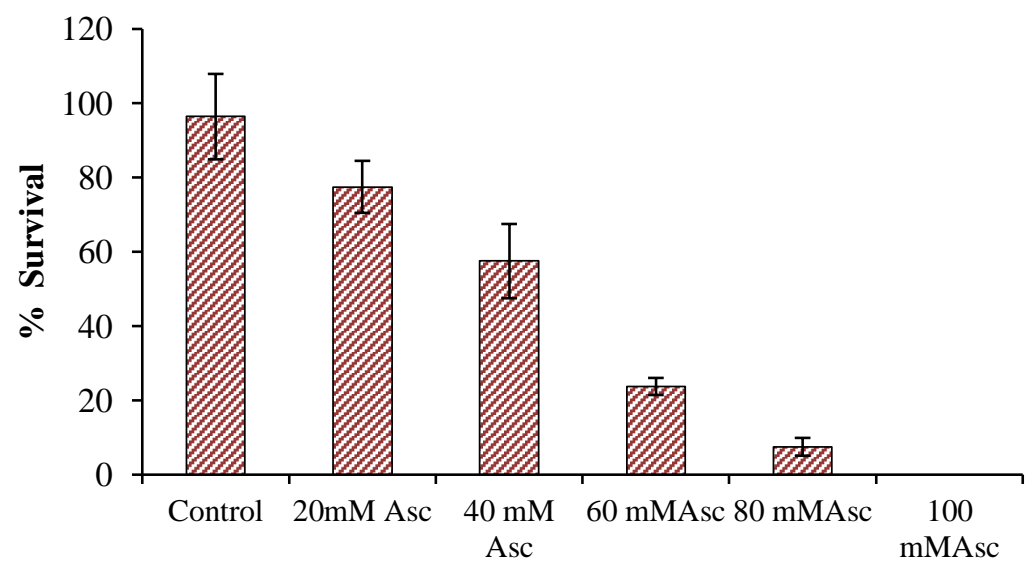

Ascorbic acid concentration

Figure 1. Standardization of Ascorbic acid dose. Values are shown as means $\pm S D(n=20)$. Significance is based on $\mathrm{p}<0.05$ compared with Control group values. $* \mathrm{p}<0.05, * *=\mathrm{p}<0.01, * * *=\mathrm{p}<0.001$.

The dose of $10 \mathrm{mM}$ ascorbic acid was used for further investigation as the SOD and PCC activities of $10 \mathrm{mM}$ ascorbic acid did not vary significantly from that of the control group. Lipid peroxidation was least in this group in comparison to the higher concentrations of ascorbic acid. Co-supplementation of $10 \mathrm{mM}$ Asc with D-Gal treatment significantly reduced the stress caused by D-Gal. The observed beneficial outcome of ascorbic acid on larvae of $M$. domestica at this dose may be owing to its antioxidant property. D-Gal was reported to accelerate the aging process by increasing oxidative stress in D. melanogaster and $M$. domestica [26]. In this study, the D-Gal ingestion significantly elevated the activities of all studied antioxidant enzymes. Comparable results were found on gut compartments of $M$. domestica [37].

The high activities of these antioxidant enzymes were found to curb the formation of oxidative radicals, which may cause impairment of biomolecules like proteins, fats, and DNA $[63,64]$. SOD is directed towards the dismutation of the superoxide anion [64, 65]. It is the chief enzyme that eliminates the superoxide anion $\left(\mathrm{O}^{-2}\right)$. Boro and Jayakumar (2020) found that thermal stress significantly increased SOD levels in the midgut of Samia ricini [66]. 
$* * *=p<0.001$.

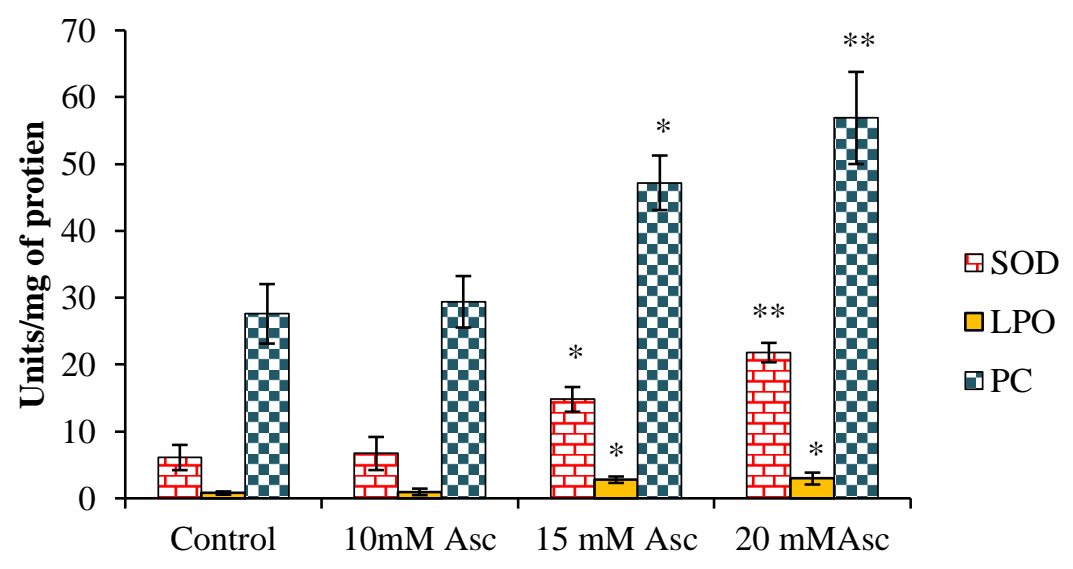

Ascorbic acid concentration

Figure 2. Standardization of Ascorbic acid concentration by antioxidant assays. Superoxide dismutase (SOD) activity is expressed as Units/mg Protein. Lipid Peroxidation (LPO) levels are expressed as nmol MDA formed/mg tissue. Protein carbonylation (PC) values are expressed as nmol $/ \mathrm{mg}$ protein. Values are shown as means $\pm \mathrm{SD}(\mathrm{n}=10)$. Significance is based on $\mathrm{p}<0.05$ compared with Control group values. $* \mathrm{p}<0.05, * *=$ $\mathrm{p}<0.01, * * *=\mathrm{p}<0.001$

\subsection{Gustatory assay.}

The larvae of all the four treatment groups did not show any significant difference in the color index of the feeding assay (one-way analysis of variance, $p>0.05$ ) (Figure. 3). These observations thus confirm that the results obtained in the further experiments are attributed to the presence of the compound used for treatment (Ascorbic acid and D- Galactose) and not because of the change in feeding behavior.

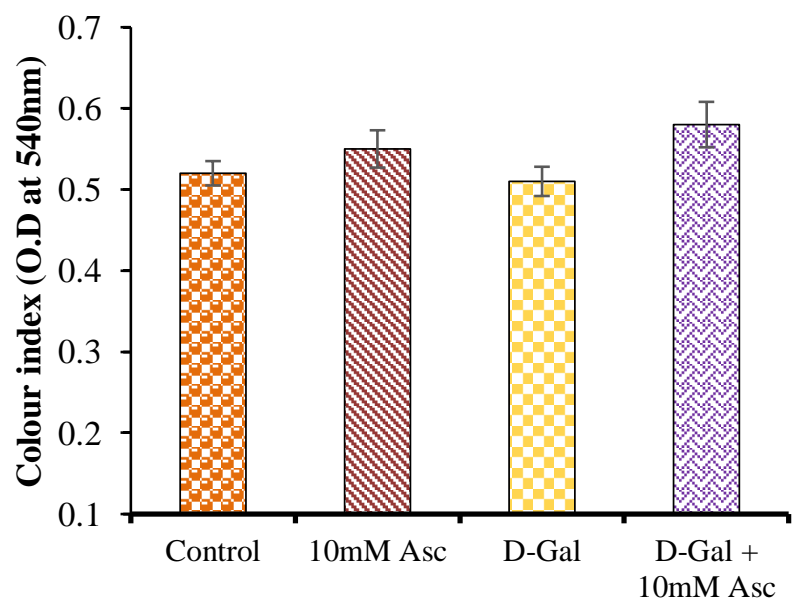

Figure 3. Gustatory assay in $3^{\text {rd }}$ instar larvae of $M$. domestica on each of the four diet groups. Values are shown as means $\pm \operatorname{SE}(n=10)$. Significance is based on $p<0.05$ compared with Control group values.

\subsection{Biochemical assays.}

A significant three-fold rise in the SOD activity of the larval group treated with D-Gal $(\mathrm{p}<0.05)$ was observed (Figure 4). Although there was a two-fold rise in SOD levels of $10 \mathrm{mM}$ Asc and D-Gal co-treated group compared to control ( $\mathrm{p}<0.05)$, it was significantly less when compared with the D-gal treated group alone. There was no significant difference in the SOD levels of the control and 10mM Asc treated groups (Figure 4). High-dose of Ascorbic acid decreased the SOD activity, exhibiting pro-oxidant nature at higher concentrations. Whereas 
10mM Asc dose has improved SOD activity in the D-Gal co-treated group, which clearly proves that it performs an imperative role in scavenging O-2, thus directly functioning as an antioxidant. It is possible that the administration of low doses of Ascorbic acid averted the decline in SOD activity caused due to D-Gal-induced oxidative damage in $M$. domestica.

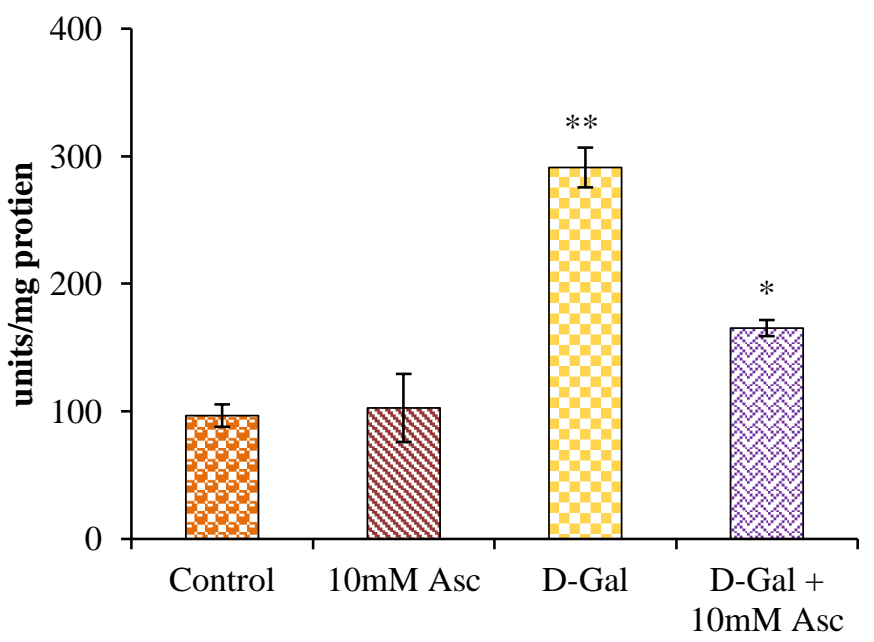

Figure 4. SOD activity (Units/mg Protein) in $M$. domestica Larvae. Values are shown as means \pm SD $(n=10)$. Significance is based on $\mathrm{p}<0.05$ compared with Control group values. $* \mathrm{p}<0.05, * *=\mathrm{p}<0.01, * * *=\mathrm{p}<0.001$.

During the assessment of another important antioxidant enzyme, GST, it was seen that there is no significant difference in the GST activities of the control and 10mM Asc treated groups (Figure 5). However, a significant rise in the GST activities was observed in the larvae treated with the D-Gal (three-fold rise) and D-Gal + $10 \mathrm{mM}$ Asc co-treatment group (two-fold rise) as compared to the control group. An increase in the GST activity appears to be the response to increased oxidative radicals.

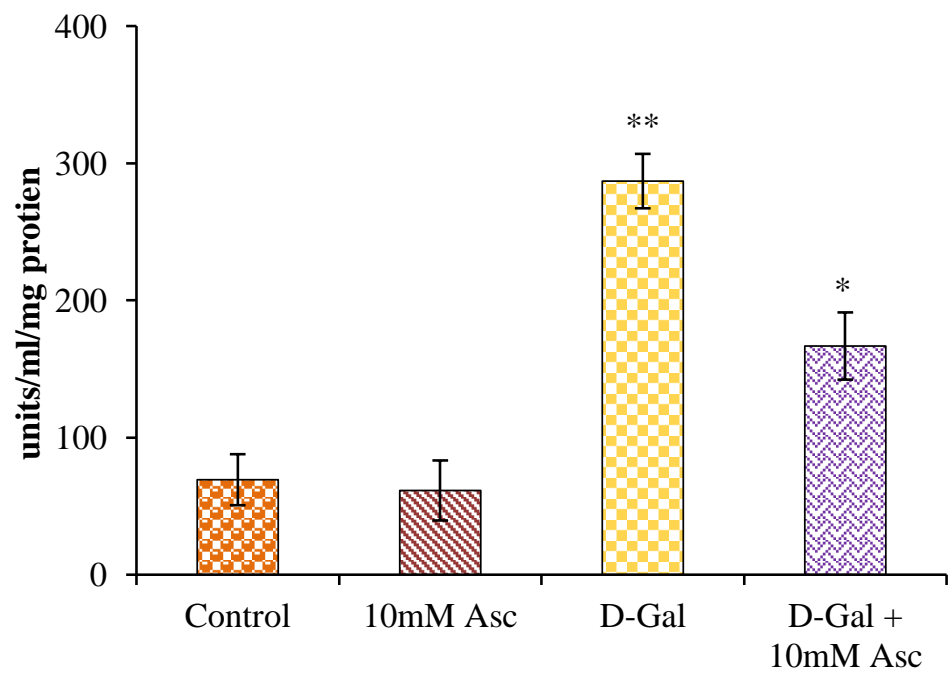

Figure 5. GST activity (Units/ml/mg Protein) in $M$. domestica Larvae. Values are shown as means \pm SD $(n=10)$. Significance is based on $\mathrm{p}<0.05$ compared with Control group values. $* \mathrm{p}<0.05, * *=\mathrm{p}<0.01, * * *=\mathrm{p}<0.001$.

Catalase (CAT) activity of treated and untreated groups in $M$. domestica larvae is shown in Figure 6. D-Gal treated group showed a two-fold increase in the CAT activity $(\mathrm{p}<0.05)$, whereas a three-fold rise was observed in $\mathrm{D}-\mathrm{Gal}+10$ mMAsc group $(\mathrm{p}<0.01)$. A major defense against $\mathrm{H}_{2} \mathrm{O}_{2}$ toxicity is via enzymatic removal by catalase [67-69]. We found increased catalase activity in D-Gal treated larvae. But its activity in D-Gal $+10 \mathrm{mM}$ Asc co-exposure 
groups was found to be very high. This was not expected since catalase is only active at high concentrations of $\mathrm{H}_{2} \mathrm{O}_{2}$ due to its low affinity towards its substrate [69].

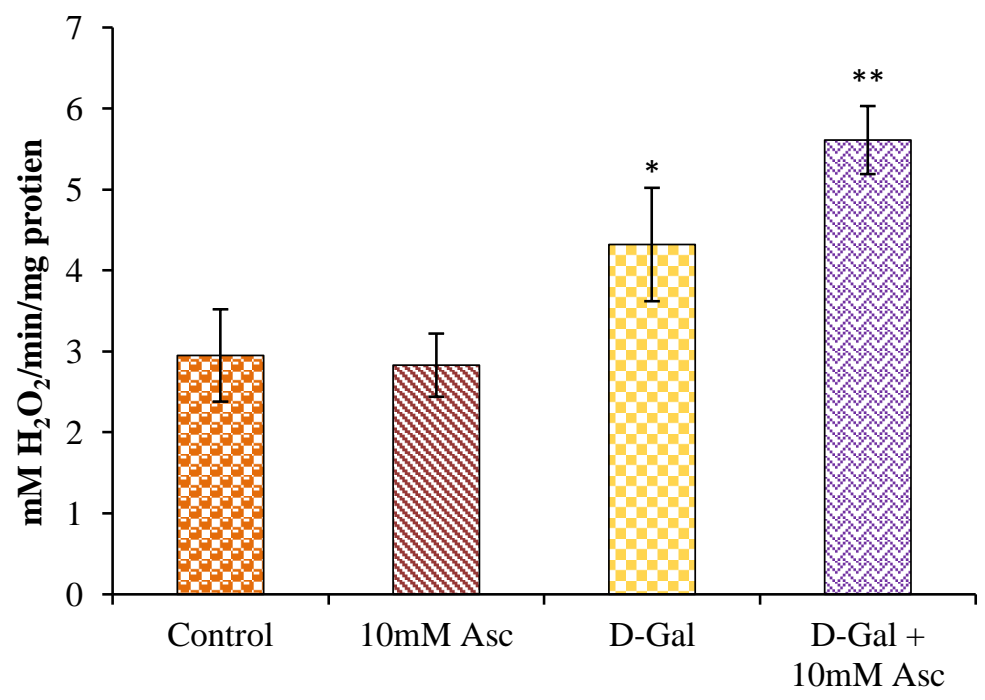

Figure 6. CAT activity (in $\mathrm{mmol} \mathrm{H}_{2} \mathrm{O}_{2}$ reduced/min/mg Protein) in M. domestica larva Values are shown as means $\pm \mathrm{SD}(\mathrm{n}=10)$. Significance is based on $\mathrm{p}<0.05$ compared with Control group values. ${ }^{*} \mathrm{p}<0.05,{ }^{* *}=$ $\mathrm{p}<0.01, * * *=\mathrm{p}<0.001$

In insect cells, removal of $\mathrm{H}_{2} \mathrm{O}_{2}$ is determined based on CAT and/or APOX activity [70]. APOX enzymes employ ascorbate as a substrate for the detoxification of peroxides such as hydrogen peroxide. Thus they catalyze the reaction of transfer of electrons from ascorbate to peroxide, generating products as de-hydro ascorbate and water [71]. Also, the APOX activity was substantially augmented in the D-Gal treated group (three-fold) compared to the control. In addition, the activity of this enzyme showed a two-fold increase in D-Gal $+10 \mathrm{mM}$ Asc group compared to the control (Figure 7).

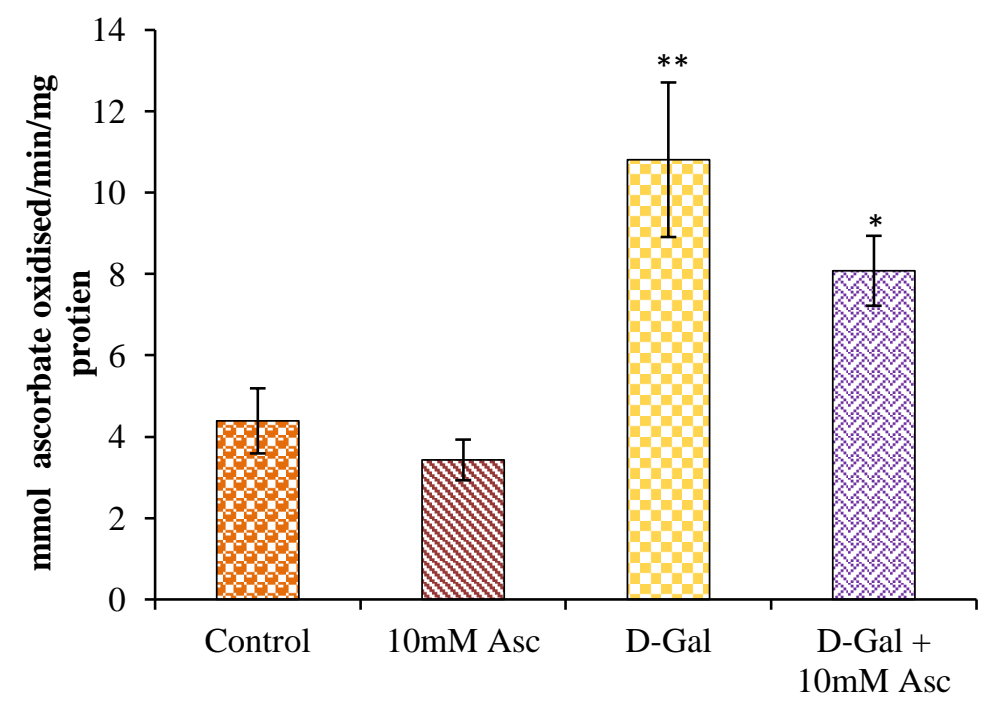

Figure 7. APOX activity (mmol ascorbate oxidized $/ \mathrm{min} / \mathrm{mg}$ Protein) in M. domestica larvae Values are shown as means $\pm \mathrm{SD}(\mathrm{n}=10)$. Significance is based on $\mathrm{p}<0.05$ compared with Control group values. $* \mathrm{p}<0.05, * *=$ $\mathrm{p}<0.01, * * *=\mathrm{p}<0.001$

There was no significant difference in the APOX activities of the control and $10 \mathrm{mM}$ Asc treated group. APOX stimulation with D-Gal in the larval tissue recommends its role in removing intracellular $\mathrm{H}_{2} \mathrm{O}_{2}$ residues that are not removed by the catalase [25]. 
The MDA levels, a biomarker for lipid peroxidation, were significantly enhanced (twofold) in D- gal treated $M$. domestica larvae and slightly (but non-significantly) reduced in a group co-treated with ascorbic acid (Figure 8). The other three groups did not demonstrate any significant variation in their MDA levels. The biological membranes can be damaged by phospholipid deterioration, their primary molecular components [72, 73]. Lipid membranes enclosing the cellular organelles get damaged due to lipid peroxidation as an outcome of elevated oxidative stress. This leads to loss of membrane fluidity and integrity [74-77]. Lipid peroxidation occurring in membrane lipids plays a crucial role in the physiology and pathology of the cell [78]. There exists a number of membrane-bound enzymes whose activities are hampered by lipid peroxidation [79]. Decreased lipid peroxidation values in the Ascorbic acid co-treated group than the D-Gal alone treated group shows its antioxidant properties. This marks the healthy status of the cell mainly due to lysosomal clearance.

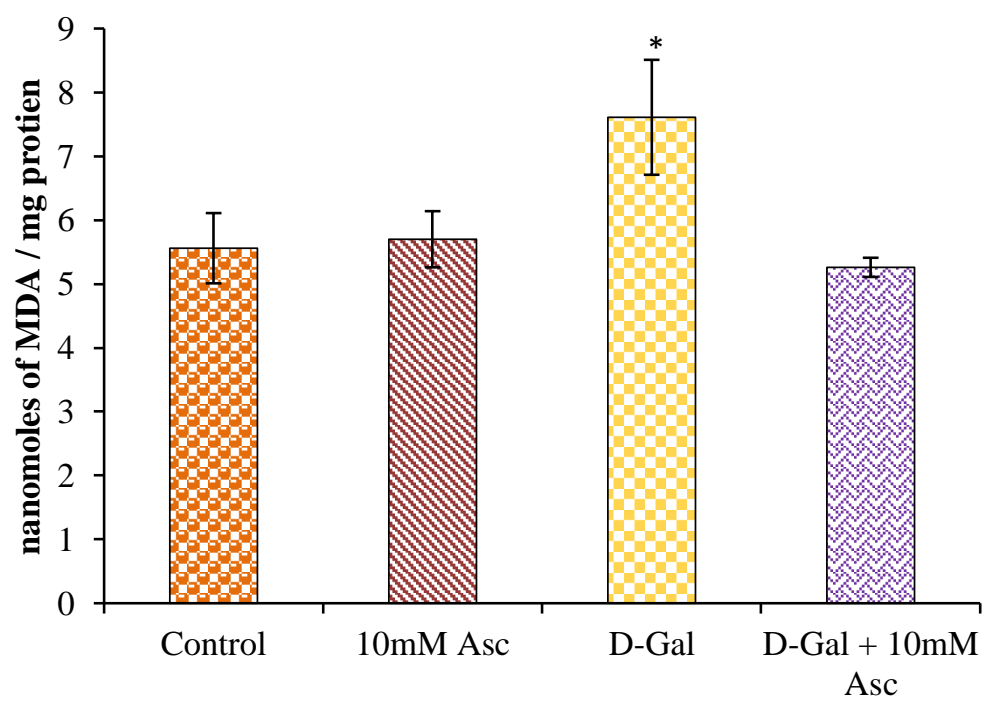

Figure 8. Lipid Peroxidation (LPO) values (nanomoles of TBARS formed /mg Protein) in M. domestica larvae Values are shown as means $\pm \mathrm{SD}(\mathrm{n}=10)$. Significance is based on $\mathrm{p}<0.05$ compared with Control group values. $* \mathrm{p}<0.05, * *=\mathrm{p}<0.01, * * *=\mathrm{p}<0.001$.

Moreover, a significant three-fold rise in the ACP activities of D- Gal treated group and a two-fold increase in D-Gal $+10 \mathrm{mM}$ Asc group as compared to the control group was seen (Figure 9). No substantial difference was found in the ACP activities of the control group and 10 mMAsc treated groups. ACP has established substantial consideration in developmental studies because of its association with histolysis. It is well known that acid phosphatase hydrolyzes an array of ortho-phosphorylation reactions [80]. Lysosomal ACP is transported as a transmembrane protein to dense lysosomes.

The pathway of lysosomal ACP to lysosomes includes passage through the plasma membrane [81]. Injured lysosomes are reported to release hydrolytic enzymes in the cytoplasm, inducing auto degradation of cellular proteins; it also causes impairment of endoplasmic reticulum, hindering the process of protein synthesis and intracellular transport of vital compounds $[28,82,83]$. This indicates that the increased activity of ACP in the present study may result from an increased number of lysosomes. 


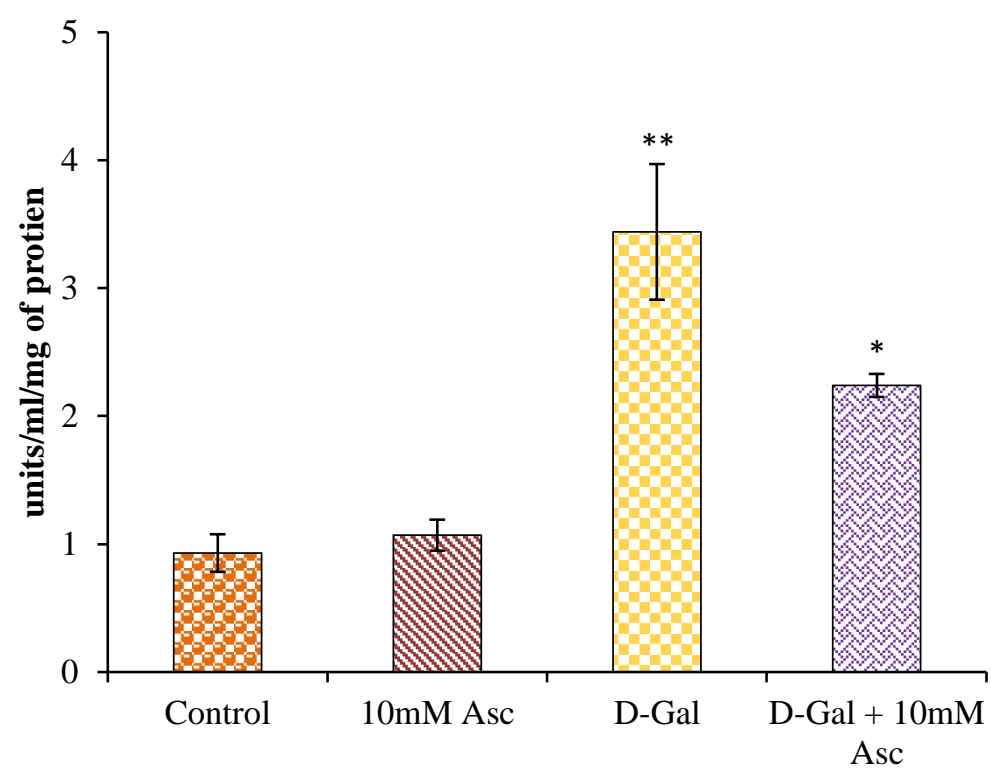

Figure 9. Acid Phosphatase (ACP) (units/ml/mg of protein) in M. domestica larvae. Values are shown as means $\pm \mathrm{SD}(\mathrm{n}=10)$. Significance is based on $\mathrm{p}<0.05$ compared with Control group values. $* \mathrm{p}<0.05, * *=\mathrm{p}<0.01, * * *=$ $\mathrm{p}<0.001$.

No significant difference was evident in the Protein Carbonylation (PCC) level of the control and 10mM Asc treated group. But a significant three-fold rise in the PCC levels of the D-Gal and D-Gal + 10 mMAsc(two-fold rise) co-treated groups were observed (Figure 10). Protein carbonyls, the markers of protein oxidation, can be formed by several mechanisms, which include: the direct oxidative breaking of the peptide chain, or by oxidation of the specific amino acid residues like lysine, proline, arginine, and threonine, or modification of lysine, histidine, and cysteine residues by aldehydes, such as Malondialdehyde (MDA) and 4hydroxynonenal (HNE) [62].

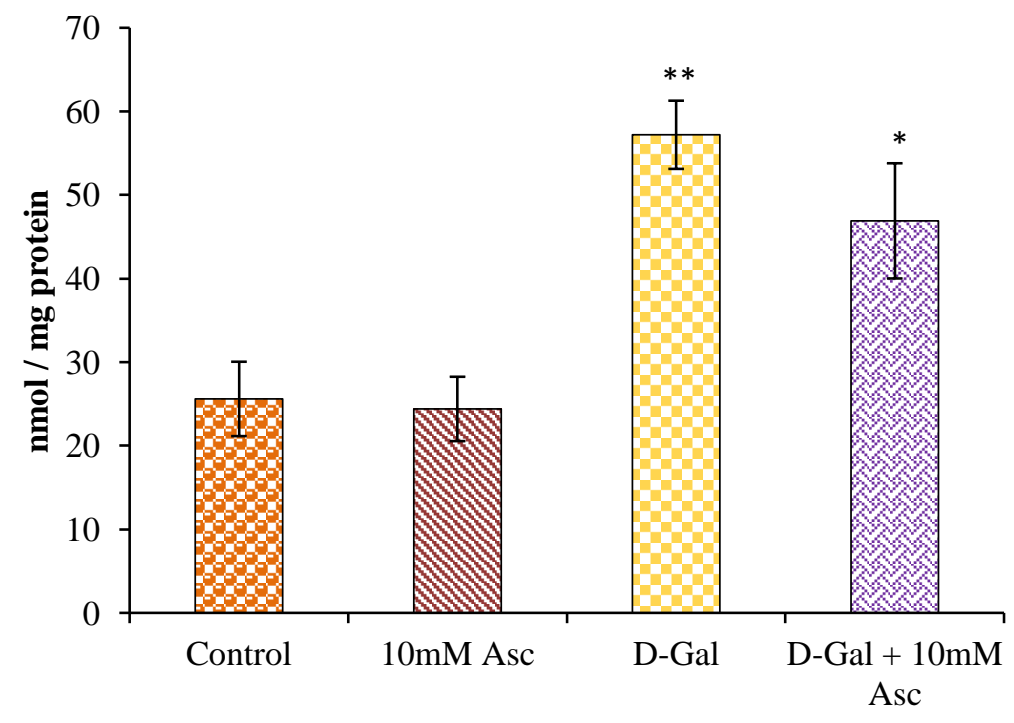

Figure 10. Protein Carbonylation (PCC) (nmol/ $\mathrm{mg}$ protein) in $M$. domestica larvae. Values are shown as means $\pm \mathrm{SD}(\mathrm{n}=10)$. Significance is based on $\mathrm{p}<0.05$ compared with Control group values. $* \mathrm{p}<0.05, * *=$ $\mathrm{p}<0.01, * * *=\mathrm{p}<0.001$

Increased PCC values in D-Gal treated groups may be due to the deleterious effects of D-gal induced oxidative stress on proteins. Oxidative modifications to proteins have been implicated in numerous conditions including aging, and neurodegenerative diseases such as Alzheimer's disease and Parkinson's disease [84-87]. 
3.4. Effect of ascorbic acid and D-Gal on pupal viability and percent eclosion studies.

There was no evident difference in the survival rate of larvae reared in all treatment groups. The larvae survived in all the groups, but differences in their pupation rates were registered. Amongst all the treatment groups D- Gal treated larval group showed a significant (9.38\%) decrease in the percent pupation rate. The decrease in the pupation rate of the D-Gal $+10 \mathrm{mM}$ Asc co-treated group (6.81\%) was not significant compared to the control group. The percent $(\%)$ pupation of the $10 \mathrm{mM}$ Asc treated group was higher $(70.27 \%)$ compared to all treatment groups, but it was not significant (Figure 11).

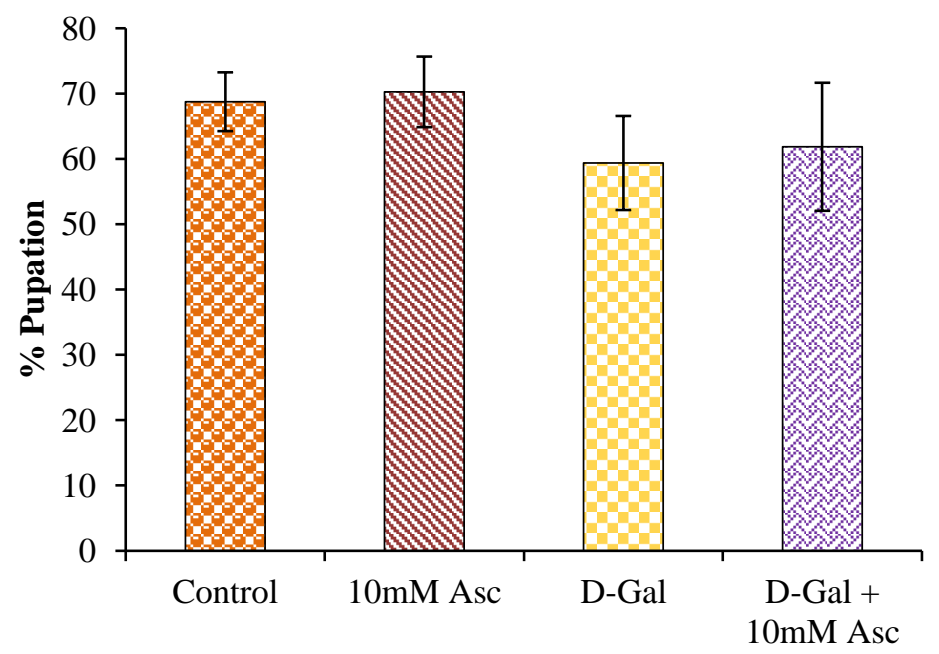

Figure 11. Effect of Ascorbic acid diet supplementation on percentage (\%) pupation in M. domestica larvae.

(The bars represent the mean of live pupae \pm SE. $*$ p $<0.05$ vs. control group.)

The survival of pupae was assessed by considering their eclosion rate. D-Gal-treated pupae showed a significant $(7.27 \%)$ decrease in the percent eclosion. Though D-Gal $+10 \mathrm{mM}$ Asc group showed a 5\% decrease in eclosion, it was not significant. Similarly, the $10 \mathrm{mM}$ Asc treated group showed a $5.23 \%$ increase in percent eclosion, but it was not significantly diverse compared to the control group eclosion rate. (Figure 12).

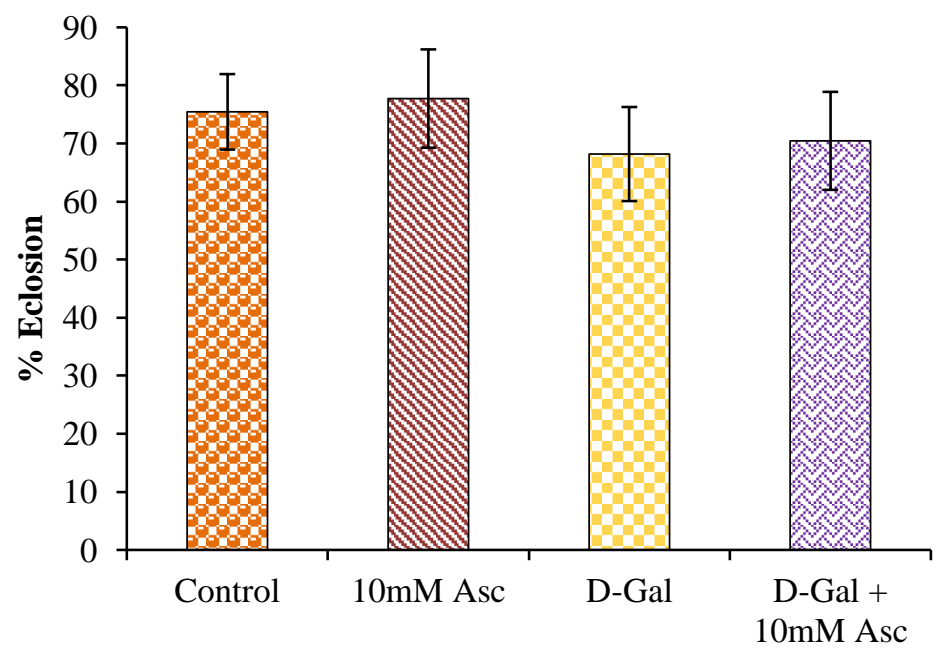

Figure 12. Effect of Ascorbic acid diet supplementation on percentage (\%) eclosion in M. domestica larvae (The bars represent mean of adult eclosion form pupae \pm SE. ${ }^{*} p<0.05$ vs. control group.)

The survival of larvae reared on all treatment groups was not found to be affected. But we found an increase in pupation rate in the ascorbic acid-treated group. Similar results were reported by Jumbo-Lucioni et. al. (2013) in D. melanogaster [88]. The survival of pupae was 
also found to be affected by D- gal, as we found decreased adult eclosion in this group. These results indicate that $\mathrm{D}-\mathrm{Gal}$ is affecting the developmental stages of the $M$. domestica. The larval survival was not affected, but the pupation rates were hampered, indicating the larval to pupal developmental damage. Ascorbic acid was found to increase the percent pupation rate of $M$. domestica, whereas there was no difference found in the pupation rate of the Control and D$\mathrm{Gal}+10$ mMAsc co-treated group.

This suggests that modification of larval diets has a significant effect on the pupation rates. Some studies have shown that modification of larval diet affected the pupal and adult characters [89- 93].

\section{Conclusions}

The present study concludes that ascorbic acid can effectively minimize the deleterious effects of D-Gal when supplemented at lower doses but fails to do so at higher concentrations, enforcing severe impairment itself.

\section{Funding}

University Grants Commission- Career Advancement Scheme (UGC-CAS III) for the financial support.

\section{Acknowledgments}

Authors thank the Department of Science \& Technology- Promotion of University Research and Scientific Excellence (DST- PURSE), Departmental Research and Development Programme grant (DRDP).

\section{Conflicts of Interest}

The authors declare no conflict of interest.

\section{References}

1. Asard, H.; May, J. M.; Smirnoff, N. Vitamin C: Functions and Biochemistry in Animals and Plants. London: BIOS Scientific Publishers 2004, 173-202, https://doi.org/10.1201/9780203500002.

2. Snezhkina, A. V.; Kudryavtseva, A. V.; Kardymon, O. L.; Savvateeva, M. V.; Melnikova, N. V.; Krasnov, G. S.; Dmitriev, A. A. ROS Generation and Antioxidant Defense Systems in Normal and Malignant Cells. Oxid. Med. Cell. Longev. 2019, 6175804, https://doi.org/10.1155/2019/6175804.

3. Di Meo, S.; Venditti, P. Evolution of the Knowledge of Free Radicals and Other Oxidants. Oxid. Med. Cell. Longev. 2020, 9829176, https://doi.org/10.1155/2020/9829176.

4. Nita, M.; Grzybowski, A. The Role of the Reactive Oxygen Species and Oxidative Stress in the Pathomechanism of the Age-Related Ocular Diseases and Other Pathologies of the Anterior and Posterior Eye Segments in Adults. Oxid. Med. Cell. Longe. 2016, 3164734, https://doi.org/10.1155/2016/3164734.

5. Lobo, V.; Patil, A.; Phatak, A.; Chandra, N. Free radicals, antioxidants and functional foods: Impact on human health. Pharmacognosy Review 2010, 4, 118-126, http://doi.org/10.4103/0973-7847.70902.

6. He, L.; He, T.; Farrar, S.; Ji, L.; Liu, T.; Ma, X. Antioxidants Maintain Cellular Redox Homeostasis by Elimination of Reactive Oxygen Species. Cell Physiol Biochem. 2017, 44, 532-553, http://doi.org/10.1159/000485089.

7. Gulcin, İ. Antioxidants and antioxidant methods: an updated overview. Archives of Toxicology 2020, 94, 651-715, https://doi.org/10.1007/s00204-020-02689-3.

8. Surai, P.F.; Kochish, I.I.; Fisinin, V.I.; Kidd, M.T. Antioxidant Defence Systems and Oxidative Stress in Poultry Biology: An Update. Antioxidants 2019, 8, https://doi.org/10.3390/antiox8070235. 
9. Aebi, H. Catalase in vitro. Methods Enzymol. 1984, 105, 121-126, http://doi.org/10.1016/s00766879(84)05016-3.

10. Aisen, P.; Cohen, G.; Kang, J. O. Iron Toxicosis. International Review of ExperimentalPathology 1990, 31 , 1-46, https://doi.org/10.1016/B978-0-12-364931-7.50006-9.

11. Frei, B. Efficacy of Dietary Antioxidants to Prevent Oxidative Damage and Inhibit Chronic Disease. J. Nutri. 2004, 134, 3196S-3198S, http://doi.org/10.1093/jn/134.11.3196S.

12. Huang, D. Dietary Antioxidants and Health Promotion. Antioxidants (Basel) 2018, 7, 9, http://doi.org/10.3390/antiox7010009.

13. Bahadorani, S.; Bahadorani, P.; Phillips, J.; Hillike, A. The effects of vitamin supplementation on Drosophila life span under normoxia and under oxidative stress. The Journals of Gerontology. Series A, Biological Sciences and Medical Sciences 2008, 63, 35-42, http://doi.org/10.1093/gerona/63.1.35.

14. Basu, S. Fatty acid oxidation and isoprostanes: Oxidative strain and oxidative stress. Prostaglandins, Leukotrienes and Essential Fatty Acids. Prostaglandins, Leukotrienes, and Essential Fatty Acids 2010, 82, 219-25, https://doi.org/10.1016/j.plefa.2010.02.031.

15. Chakraborthy, A.; Ramani, P.; Sherlin, H. J.; Premkumar, P.; Natesan, A. Antioxidant and pro-oxidant activity of Vitamin C in oral environment. Indian J Dent Res. 2014, 25, 499-504, http://doi.org/10.4103/09709290.142547.

16. Ivanova, I. P.; Trofimova, S. V.; Piskarev, I. M. Evaluation of pro-oxidant properties of ascorbic acid. Biophysics 2013, 58, 453-456, https://doi.org/10.1134/S0006350913040076.

17. Pires, A. S.; Marques, C. R.; Encarnação, J. C.; Abrantes, A. M.; Mamede, A. C.; Laranjo, M.; Gonçalves, A. C.; Sarmento-Ribeiro, A. B.; Botelho, M. F. Ascorbic acid and colon cancer: an oxidative stimulus to cell death depending on cell profile. European Journal of Cell Biolology 2016, 95, 208218, https://doi.org/10.1016/j.ejcb.2016.04.001.

18. Putchala, M. C.; Ramani, P.; Sherlin, H. J.; Premkumar, P.; Natesan, A. Ascorbic acid and its pro-oxidant activity as a therapy for tumours of oral cavity - A systematic review. Archives of Oral Biology 2013, 58, 563-574, https://doi.org/10.1016/j.archoralbio.2013.01.016.

19. Frajese, G. V.; Benvenuto, M.; Fantini, M.; Ambrosin, E.; Sacchetti, P.; Masuelli, L.; Giganti, M. G.; Modesti, A.; Bei, R. Potassium increases the antitumor effects of ascorbic acid in breast cancer cell lines in vitro. Oncol Lett. 2016, 11, 4224-4234, https://doi.org/10.3892/ol.2016.4506.

20. Pires, A. S.; Marques, C. R.; Encarnação, J. C.; Abrantes, A. M.; Marques, I. A.; Laranjo, M.; Oliveira, R.; Casalta-Lopes, J. E.; Gonçalves, A. C.; Sarmento-Ribeiro, A. B.; Botelho, M. F.; Ascorbic acid chemosensitizes colorectal cancer cells and synergistically inhibits tumor growth. Front. Physiol. 2018, 9, 911, https://doi.org/10.3389/fphys.2018.00911.

21. Wu, T. M.; Liu, S. T.; Chen, S. Y.; Chen, G. S.; Wu, C. C.; Huang, S. M. Mechanisms and Applications of the Anti-cancer Effect of Pharmacological Ascorbic Acid in Cervical Cancer Cells. Frontiers in oncology, 2020, 10, 1483, https://doi.org/10.3389/fonc.2020.01483.

22. Beyer, R. E. The role of ascorbate in antioxidant protection of biomembranes: Interaction with vitamin $\mathrm{E}$ and coenzyme Q. Journal of Bioenerg Biomembr. 1994, 26, 349-58, https://doi.org/10.1007/BF00762775.

23. Borg, D. C.; Schaich, K. M. Pro-oxidant action of antioxidants. Handbook of Free Radicals and Antioxidants in Biomedicine 1989, (CRC press, Boca Raton), 1, 63-80.

24. Brenneisen, P.; Steinbrenner, H.; Sies, H. Selenium, oxidative stress, and health aspects. Mol Aspects Med. 2005, 26, 256-267, https://doi.org/10.1016/j.mam.2005.07.004.

25. Mathews, M. C.; Summers, C. B.; Felton, G.W. Ascorbate peroxidase: A novel antioxidant enzyme in insects. Arch Insect Biochem Physiol. 1997, 34, 57-68, https://doi.org/https://doi.org/10.1002/(SICI)15206327(1997)34:1<57::AID-ARCH5>3.0.CO;2-T.

26. Cui, X.; Wang, L.; Zuo, P.; Han, Z.; Fang, Z.; Li, W.; Liu, J. D-galactose-caused life shortening in Drosophila melanogaster and Musca domestica is associated with oxidative stress. Biogerontology 2004, 5, 317-325, https://doi.org/10.1007/s10522-004-2570-3.

27. Cui, X.; Zuo, P.; Zhang, Q.; Li, X.; Hu, Y.; Long, J.; Packer, L.; Liu, J. Chronic systemic D-galactose exposure induces memory loss, neurodegeneration, and oxidative damage in mice: protective effects of Ralpha-lipoic acid. Journal Neurosci Res. 2006, 83, 1584-90, https://doi.org/10.1002/jnr.20845.

28. Gaikwad, Y. B.; Gaikwad, S. M.; Bhawane, G. P. Effect of induced oxidative stress and herbal extracts on acid phosphatase activity in lysosomal and microsomal fractions of midgut tissue of the silkworm, Bombyx mori. Journal Insect Science 2010, 10, 1-9, https://doi.org/10.1673/031.010.11301. 
29. Haider, S.; Liaquat, L.; Shahzad, S.; Sadir, S.; Madiha, S.; Batool, Z.; Tabassum, S.; Saleem, S.; Naqvi, F.; Perveen, T. A high dose of short term exogenous D-galactose administration in young male rats produces symptoms simulating the natural aging process. Journal Life Sciences 2015, 124, 110-119, https://doi.org/10.1016/j.lfs.2015.01.016.

30. Hsieh, H. M.; Wu, W. M.; Hu, M.L. Soy isoflavones attenuate oxidative stress and improve parameters related to aging and Alzheimer's disease in C57BL/6J mice treated with D-galactose. Food Chem Toxicol. 2009, 47, 625-632, https://doi.org/10.1016/j.fct.2008.12.026.

31. Ma, J.; Wang, H.; Liu, B.; Shan, Y.; Zhou, H.; Qi, X.; Wu, W.; Jia, L. Combination of chick embryo and nutrient mixture prevent D-galactose-induced cognitive deficits, immune impairment and oxidative stress in aging rat model. Scientific Reports 2019, 9, 4092, https://doi.org/10.1038/s41598-019-40953-4.

32. Pavani, A.; Chaitanya, R. K.; Chauhan, V. K.; Dasgupta, A.; Dutta-Gupta, A. Differential oxidative stress responses in castor semilooper, Achaea Janata. Journal of Invertebrate Pathology 2015, 132, 157-164, https://doi.org/10.1016/j.jip.2015.10.002.

33. Qian, J.; Wang, X.; Cao, J.; Zhang, W.; Lu, C.; Chen, X. Dihydromyricetin attenuates D-galactose-induced brain aging of mice via inhibiting oxidative stress and neuroinflammation, Neurosci. Lett. 2021, 756, 135963, https://doi.org/10.1016/j.neulet.2021.135963.

34. Sadigh-Eteghad, S.; Majdi, A.; McCann, S. K.; Mahmoudi, J.; Vafaee, M. S.; Macleod, M. R. D-galactoseinduced brain ageing model: A systematic review and meta-analysis on cognitive outcomes and oxidative stress indices. PLOS Digital Health 2017, 12, e0184122, https://doi.org/10.1371/journal.pone.0184122.

35. Song, X.; Bao, M.; Li, D.; Li, Y. Advanced glycation in D-galactose induced mouse aging model. Mech Ageing Dev. 1999, 108, 239-251, https://doi.org/10.1016/s0047-6374(99)00022-6.

36. Wang, Y.; Cui, X.; Lin, Q.; Cai, J.; Tang, L.; Liang, Y. Active Peptide KF-8 from Rice Bran Attenuates Oxidative Stress in a Mouse Model of Aging Induced by d-Galactose, J. Agric. Food Chem. 2020, 68, 1227112283, https://doi.org/10.1021/acs.jafc.0c04358.

37. Sharbidre, A. A.; Bamane, M. B.; Dhage, P. A.; Bharmal, D. L. Prevention of D-galactose induced oxidative stress in gut compartments of Musca domestica larvae by Melatonin. Journal of Entomology and Zoology Studies 2014, 2, 220-225.

38. Xu, C.; Wenbin, L.; Binglie, Z.; Jie, Z. Mechanism of lipid peroxidation in D-galactose-induced brain aging model. Chinese Journal of Gerontology 1998, 18, 38-40, http://europepmc.org/abstract/CBA/312005.

39. Beauchamp, C.; Fridovich, I. Superoxide dismutase: improved assays and an assay applicable to acrylamide gels. Anal Biochem. 1971, 44, 276-87, https://doi.org/10.1016/0003-2697(71)90370-8.

40. Habig, W. H.; Pabst, M. J.; Jakoby, W. B. Glutathione S-transferases: The first enzymatic step in mercapturic acid formation. Journal of Biological Chemistry 1974, 249, 7130-7139.

41. Esterbauer, H.; Cheeseman, K. H. Determination of aldehydic lipid Peroxidation products: Malonaldehyde and 4-hydroxynonenal. Oxygen Radicals in Biological Systems Part B: Oxygen Radicals and Antioxidants 1990, 186, 407-21, Academic Press, https://doi.org/10.1016/0076-6879(90)86134-H.

42. Linhardt, K.; Walter, K. Phosphatase. Methods of Enzymatic Analysis, Edited by Bergmeyer HU, (New York: Academic Press) 1963, 783-785.

43. Reznick, A. Z.; Packer, L. Oxidative damage to proteins: Spectrophotometric method for carbonyl assay. Journal Methods Enzymol. 1994, 233, 357-63, https://doi.org/10.1016/s0076-6879(94)33041-7.

44. Bradford, M. M. A rapid and sensitive method for the quantitation of microgram quantities of protein utilizing the principle of protein-dye binding. Analalytical Biochemistry 1976, 72, 248-54, https://doi.org/10.1006/abio.1976.9999.

45. McGregor, G.P.; Biesalski, H. K. Rationale and impact of vitamin C in clinical nutrition. Journal Current Opinion in Clinical Nutrition and Metabolic Care 2006, 697-703, https://doi.org/10.1097/01.mco.0000247478.79779.8f.

46. Osiecki, M.; Ghanavi, P.; Atkinson, K.; Nielsen, L. K.; Doran, M. R. The ascorbic acid paradox. Biochem Biophys Res Commun. 2010, 400, 466-470, https://doi.org/10.1016/j.bbrc.2010.08.052.

47. Scheffler, J.; Bork, K.; Bezold, V.; Rosenstock, P.; Gnanapragassam, V. S.; Horstkorte, R. Ascorbic acid leads to glycation and interferes with neurite outgrowth. Exp. Gerontol. 2019, 117, 25-30, https://doi.org/10.1016/j.exger.2018.08.005.

48. Rehman, A.; Collis, C.S.; Yang, M.; Kelly, M.; Diplock, A.T.; Halliwell, B.; Rice-Evans, C. The effects of iron and vitamin C co-supplementation on oxidative damage to DNA in healthy volunteers. Biochem Biophys Res Commun. 1998, 246, 293-8, https://doi.org/10.1006/bbrc.1998.8592. 
49. Sokol, R. J. Antioxidant defenses in metal-induced liver damage. Semin Liver Dis. 1996, 16, 39-46, https://doi.org/10.1055/s-2007-1007217.

50. Timoshnikov, V. A.; Kobzeva, T. V.; Polyakov, N. E.; Kontoghiorghes, G. J. Redox Interactions of Vitamin $\mathrm{C}$ and Iron: Inhibition of the Pro-Oxidant Activity by Deferiprone. Int. J. Mol. Sci. 2020, 21, https://doi.org/10.3390/ijms21113967.

51. Gonza'lez, M. J.; Miranda-Massari, J. R.; Mora, E. M. Orthomolecular oncology review: ascorbic acid and cancer 25 years late. Integr Cancer Ther. 2005, 4, 32-44, https://doi.org/10.1177/1534735404273861.

52. Davies, J.E.; Ellery, P.M.; Hughes, R.E. Dietary ascorbic acid and life span of guinea pigs. Exp Gerontol. 1977, 12, 215-6, https://doi.org/10.1016/0531-5565(77)90008-0.

53. Ishii, N.; Homma, T.; Guo, X.; Yamada, K.; Yamada, S.; J. Fujii. Ascorbic acid prevents Nnitrosodiethylamine-induced hepatic injury and hepatocarcinogenesis in Akr1a-knockout mice. Toxicol. Lett. 2020, 333, 192-201, https://doi.org/10.1016/j.toxlet.2020.08.005.

54. Massie, H. R.; Aiello, V. R.; Doherty, T. J. Dietary vitamin C improves the survival of mice. Gerontology 1984, 30, 371-375, https://doi.org/10.1159/000212659.

55. Carr, A.; Frei, B. Does vitamin C act as a pro-oxidant under physiological conditions? FASEB Journal 1999, 13,1007-24, https://doi.org/10.1096/fasebj.13.9.1007.

56. Cimmino, L.; Neel, B. G.; Aifantis, I. Vitamin C in Stem Cell Reprogramming and Cancer. Trends Cell Biol. 2018, 28, 698-708, https://doi.org/10.1016/j.tcb.2018.04.001.

57. Frei, B.; Lawson, S. Vitamin C and cancer revisited. Proceedings of the National Academy of Sciences of the United States of America 2008, 105, 11037-11038, https://doi.org/10.1073/pnas.0806433105.

58. Ohno, S.; Ohno, Y.; Suzuki, N.; Soma, G. I.; Inoue, M. High-dose vitamin C (ascorbic acid) therapy in the treatment of patients with advanced cancer. Anticancer Research 2009, 29, 809-815.

59. Reczek, C. R.; Chandel, N. S. Revisiting vitamin C and cancer. Science 2015, 350, 1317-1318, https://doi.org/10.1126/science.aad8671.

60. Clément, M.V.; Ramalingam, J.; Long, L. H.; Halliwell, B. The in vitro cytotoxicity of ascorbate depends on the culture medium used to perform the assay and involves hydrogen peroxide. Antioxid Redox Signal 2001, 3, 157-63, https://doi.org/10.1089/152308601750100687.

61. Otero, P.; Viana, M.; Herrera, E.; Bonet, B. Antioxidant and pro-oxidant effects of ascorbic acid, dehydroascorbic acid and flavonoids on LDL submitted to different degrees of oxidation. Free Radical Res. 1997, 27, 619-26, https://doi.org/10.3109/10715769709097865.

62. Berlett B. S.; Stadtman E. R. Protein oxidation in aging, disease and oxidative stress. J Biol Chem. 1997, 272, 20313-6, https://doi.org/10.1074/jbc.272.33.20313.

63. Gupta, N.; Verma, K.; Nalla, S.; Kulshreshtha, A.; Lall, R.; Prasad, S. Free Radicals as a Double-Edged Sword: The Cancer Preventive and Therapeutic Roles of Curcumin. Journal Molecules 2020, 25, https://doi.org/10.3390/molecules25225390.

64. Fridovich, I. The biology of oxygen radicals. Journal Science 1978, 201, 875-880, https://doi.org/10.1126/science.210504.

65. Islam, M.N.; Rauf, A.; Fahad, F.I.; Bin Emran, T.; Mitra, S.; Olatunde, A.; Shariati, M.A.; Rebezov, M.; Rengasamy, K.R.R.; Mubarak, M.S. Superoxide dismutase: an updated review on its health benefits and industrial applications. Critical Reviews in Food Science and Nutrition 2021, 1-19, https://doi.org/10.1080/10408398.2021.1913400.

66. Boro, R. C.; Jayakumar, S. Studies on enzymes Superoxide dismutase and catalase in midgut of Samia ricini under thermal stress condition. Journal of Entomological Research 2020, 44, 87-91, https://doi.org/10.5958/0974-4576.2020.00016.X.

67. Ahmad, S.; Pristos, C.A.; Bowen, S. M.; Heisler, C. R.; Blomquist, G. J.; Pardini, R. S. Subcellular distribution and activities of superoxide dismutase, catalase, glutathione peroxidase and glutathione reductase in the southern armyworm, Spodoptera eridania. Archs Insect Biochem. Physiol. 1988, 7, 173-186, https://doi.org/10.1002/arch.940070304.

68. Nandi, A.; Yan, L. J.; Jana, C. K.; Das, N. Role of Catalase in Oxidative Stress- and Age-Associated Degenerative Diseases. Oxidative medicine and cellular longevity 2019, 9613090, https://doi.org/10.1155/2019/9613090.

69. Paes, M.C.; Oliveira, M. B.; Oliveira, P. L. Hydrogen peroxide detoxification inthe midgut of the bloodsucking insect, Rhodnius prolixus. Archiv Insect Biochem Physiol. 2001, 48, 63-71, https://doi.org/10.1002/arch.1058. 
70. Felton, G. W.; Summers C. B. Antioxidant systems in insects. Arch Insect Biochem Physiol. 1995, $29,187-$ 197, https://doi.org/10.1002/arch.940290208.

71. Raven, E. L. Peroxidase-catalyzed oxidation of ascorbate. Structural, spectroscopic and mechanistic correlations in ascorbate peroxidase. Subcell Biochem. 2000, 35, 317- 349, https://doi.org/10.1007/0-30646828-X_10.

72. Donato, S.; Sohal, R. S. Relation of lipofuscin accumulation of aging. Florini JR, Adelman RC, Roth GS, ediotrs. CRC handbook of Biochemistry in aging (CRC Press) 1980, 221-227.

73. Tappel, A. L. Measurement and protection from in vivo lipid peroxidation. Pryor WA editor. Free Radical Biology IV: (Academic Press) 1980, 1-47.

74. Andrade, S.; Ramalho, M. J.; Loureiro, J.A.; Pereira, M.C. The biophysical interaction of ferulic acid with liposomes as biological membrane model: The effect of the lipid bilayer composition. Journal Mol. Liq. 2021, 324, 114689, https://doi.org/10.1016/j.molliq.2020.114689.

75. Chng, C. P.; Sadovsky,Y.; Hsia, K.J.; Huang, C. Site-specific peroxidation modulates lipid bilayer mechanics. Extrem. Mech. Lett. 2021, 42, 101148, https://doi.org/10.1016/j.eml.2020.101148.

76. Paciorek, P.; Żuberek, M.; Grzelak, A. Products of Lipid Peroxidation as a Factor in the Toxic Effect of Silver Nanoparticles. Materials 2020, 13, https://doi.org/10.3390/ma13112460.

77. Wong-Ekkabut, J.; Xu, Z.; Triampo, W.; Tang, I. M.; Tieleman, D. P.; Monticelli, L. Effect of lipid peroxidation on the properties of lipid bilayers: a molecular dynamics study. Biophysical Journal 2007, 93, 4225-4236, https://doi.org/10.1529/biophysj.107.112565.

78. Sadžak, A.; Mravljak, J.; Maltar-Strmečki, N.; Arsov, Z.; Baranović, G.; Erceg, I.; Kriechbaum, M.; Strasser, V.; Přibyl, J.; Šegota, S. The Structural Integrity of the Model Lipid Membrane during Induced Lipid Peroxidation: The Role of Flavonols in the Inhibition of Lipid Peroxidation. Antioxidants 2020, 9, https://doi.org/10.3390/antiox9050430.

79. Xiang, Q.-Q.; Wang, D.; Zhang, J.-L.; Ding, C.-Z.; Luo, X.; Tao, J.; Ling, J.; Shea, D.; Chen, L.-Q. Effect of silver nanoparticles on gill membranes of common carp: Modification of fatty acid profile, lipid peroxidation and membrane fluidity. Environmental Pollution 2020, 256, 113504, https://doi.org/10.1016/j.envpol.2019.113504.

80. Hollander, V. P. Acidphosphatase. The enzymes, Edited by Boyer, P. (Academic Press. New York) 1971.

81. Braun, M.; Waheed, A.; Von Figura, K. Lysosomal acid phosphatase is transported to lysosomes via the cell surface. EMBO Journal 1989, 8, 3633-3640, https://doi.org/10.1002/j.1460-2075.1989.tb08537.x.

82. Di Meo, S.; Reed, T. T.; Venditti, P.; Victor, V. M. Role of ROS and RNS Sources in Physiological and Pathological Conditions. Oxid. Med. Cell. Longev. 2016, 1245049, https://doi.org/10.1155/2016/1245049.

83. Zs- Nagy, I. The role of membrane structure and function in cellular aging: A review. Mech Aging Dev. 1979, 9, 237-246, https://doi.org/10.1016/0047-6374(79)90102-7.

84. Cenini, G.; Lloret, A.; Cascella, R.. Oxidative Stress in Neurodegenerative Diseases: From a Mitochondrial Point of View. Oxid. Med. Cell. Longev. 2019, 2019, 2105607, https://doi.org/10.1155/2019/2105607.

85. Dean, R.T.; Fu, S.; Stocker, R.; Davies, M. J. Biochemistry and pathology of radical-mediated protein oxidation. Biochem J. 1997, 324, 1-18, https://doi.org/10.1042/bj3240001.

86. Kim, G. H .; Kim, J. E.; Rhie, S. J.; Yoon, S. The Role of Oxidative Stress in Neurodegenerative Diseases. Exp Neurobiol. 2015, 24, 325-340, https://doi.org/10.5607/en.2015.24.4.325.

87. Liu, Z.; Zhou, T.; Ziegler, A. C.; Dimitrion, P.; Zuo, L. Oxidative Stress in Neurodegenerative Diseases: From Molecular Mechanisms to Clinical Applications. Oxid. Med. Cell. Longe. 2017, 2525967, https://doi.org/10.1155/2017/2525967.

88. Jumbo-Lucioni, P. P.; Hopson, M. L.; Hang, D.; Liang, Y.; Jones, D. P.; Fridovich-Keil, J.L. Oxidative stress contributes to outcome severity in a Drosophila melanogaster model of classic galactosemia. Dis. Model Mech. 2013, 6, 84-94, https://doi.org/10.1242/dmm.010207.

89. Astuti, L. P.; Mario, M. B.; Widjayanti, T. Preference, growth and development of Oryzaephilus surinamensis (L.)(Coleoptera: Silvanidae) on red, white and black rice in whole grain and flour form. Journal of Entomological Research 2018, 42, 461-468, https://doi.org/10.5958/0974-4576.2018.00077.4.

90. Chandrashekara, K. T.; Shakarad, M. N. Aloe vera or Resveratrol Supplementation in Larval Diet Delays Adult Aging in the Fruit Fly, Drosophila melanogaster. Journal Gerontol.: Series A. 2011, 66 A, 965-971, https://doi.org/10.1093/gerona/glr103.

91. Stanley, R. V. K.; Abraham, S. M. Administration of blue green algae Spirulina meneghiniana on the Morus alba leaves to enhanced growth rate and economic traits of silkworm. Journal of Entomological Research 2020, 44, 165-170, https://doi.org/10.5958/0974-4576.2020.00031.6. 
92. Yankit, P.; Rana, K.; Sharma, H. K.; Singh, N. Laboratory rearing and food consumption of spring bumble bee (Bombus haemorrhoidalis Smith) queens. Journal of Entomological Research 2018, 42, 233-236, https://doi.org/10.5958/0974-4576.2018.00039.7. 